\title{
PAN AFRICAN CRUSTAL EVOLUTION
}

by

Alfred Kröner

The Pan African (Late Precambrian to early Palaeozoic) was one of the major crust-forming periods in earth history. This paper outlines the structural differences between individual African foldbelts, suggesting a complex evolution involving varying degrees of horizontal plate motion, in places resembling modern plate tectonic movements. Ophiolites and sheeted dykes show that sea-floor spreading was established in the late Precambrian and that the Wilson-cycle had become an important element of orogenic evolution. Pan African belts may contain important ore deposits and some are recommended as targets for future mineral exploration.*

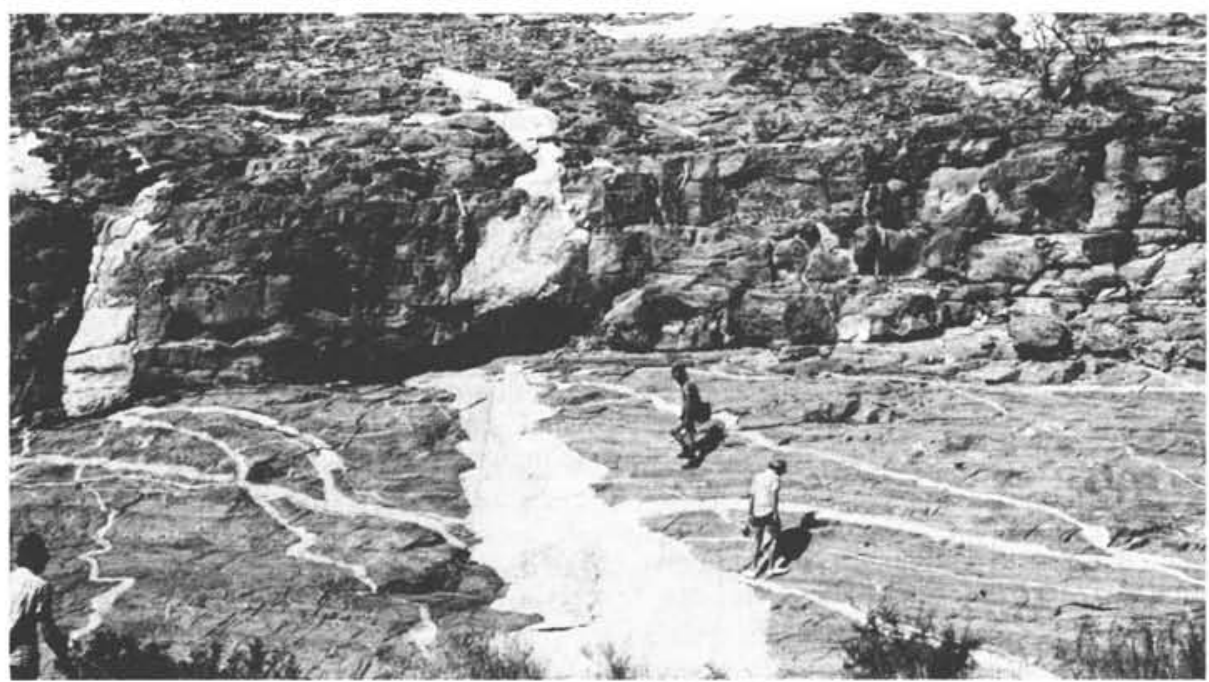

Late tectonic alaskitic granite cutting metasediments of the Khan Formation near Rössing, Damara belt, Namibia. The alaskites show strong uranium enrichment in certain areas and are probably related to anatectic melting of pre-Damara basement at about $500 \mathrm{Ma}$ ago.

\section{Introduction}

The term "Pan African" (loosely meaning "all Africa") was coined by W.Q. Kennedy (1964) who recognized "an important and widespread tectonic and thermal event" which led to "structural differentiation of an original shield into cratons and circum-structural (orogenic) areas" about $500 \mathrm{Ma}$ ago. Kennedy observed that in some areas of the continent this process involved geosynclinal sedimentation and subsequent deformation and prograde regional metamorphism, while in others, notably in East Africa, only basement rocks were apparently affected by an intense thermal event that caused granitization and reset radiometric clocks. He therefore hesitated to apply the term "orogeny" and proposed "PanAfrican thermo-tectonic episode". It is interesting to note that the phenomenon of widespread structural reactivation of older crystalline basement during this episode was seen by Kennedy (1964) as evidence against the concept of continental accretion.

Kennedy's definition was largely based on the then available $\mathrm{K}-\mathrm{Ar}$ and $\mathrm{Rb}-\mathrm{Sr}$ mineral ages which, as we know now, only reflect blocking temperatures reached late in the thermal evolution of a belt, and so the time designation of ca. $500 \mathrm{Ma}$ must be seen as relating to the final thermal rather than the entire tectonic episode.

Clifford (1967) recognized this problem, and in a detailed evaluation of radiometric data, he demonstrated that the Pan African of southern and central Africa consisted of at least two episodes - the Damaran (in the general range 450-570 $\mathrm{Ma}$ ), and the Katangan (in the range 580-680 Ma). Vail (1964) had also concluded that the Mozambique Orogeny of East Africa took place between $400 \mathrm{Ma}$ and $650 \mathrm{Ma}$ ago. The extension of the Pan African to a longer period than originally proposed by Kennedy became widely established when Vachette compiled a mineral age map of Africa (reproduced in Bessoles, 1977) which confirmed the general range from ca. $450 \mathrm{Ma}$ to about $650 \mathrm{Ma}$ ago. Also, in view of the presence of several distinct episodes during this period, the term "Pan African event" became popular in the literature.

In recent years, considerable research has taken place in these Pan African terrains and it has become clear from whole-rock and zircon isotopic data that deformation, igneous activity and metamorphism date back to more than $750 \mathrm{Ma}$ in some regions of the continent (Kröner, 1980a) and to about $1000 \mathrm{Ma}$ in the Arabian Shield (Fleck et al., 1979). Also, there were suggestions (Gass, 1977) to expand the Pan African and include the pre-tectonic cycle of sedimentation and volcanism, which would be in line with Kennedy's (1964) definition but would extend the event back to about 1000 $1100 \mathrm{Ma}$, the beginning of deposition in most Pan African belts. The problem, however, is that such extension would mean an overlap in time with the Kibaran event which, in some areas of Africa, lasted until ca. $950 \mathrm{Ma}$ ago. The problem of nomenclature is not resolved at present, though some suggestions are given at the end of this review.

It has furthermore emerged that the Pan African in its extended definition was not restricted to the African continent but was also found in all other Gondwana crustal segments (Fig. 1), thereby making it one of the most important and extensive tectono-metamorphic events of earth history. Significantly, it seems largely confined to the Southern Hemisphere.

\footnotetext{
* This is an updated and modified version of a paper presented at the 5th Conference on African Geology, Cairo, Egypt, October, 1979.
} 

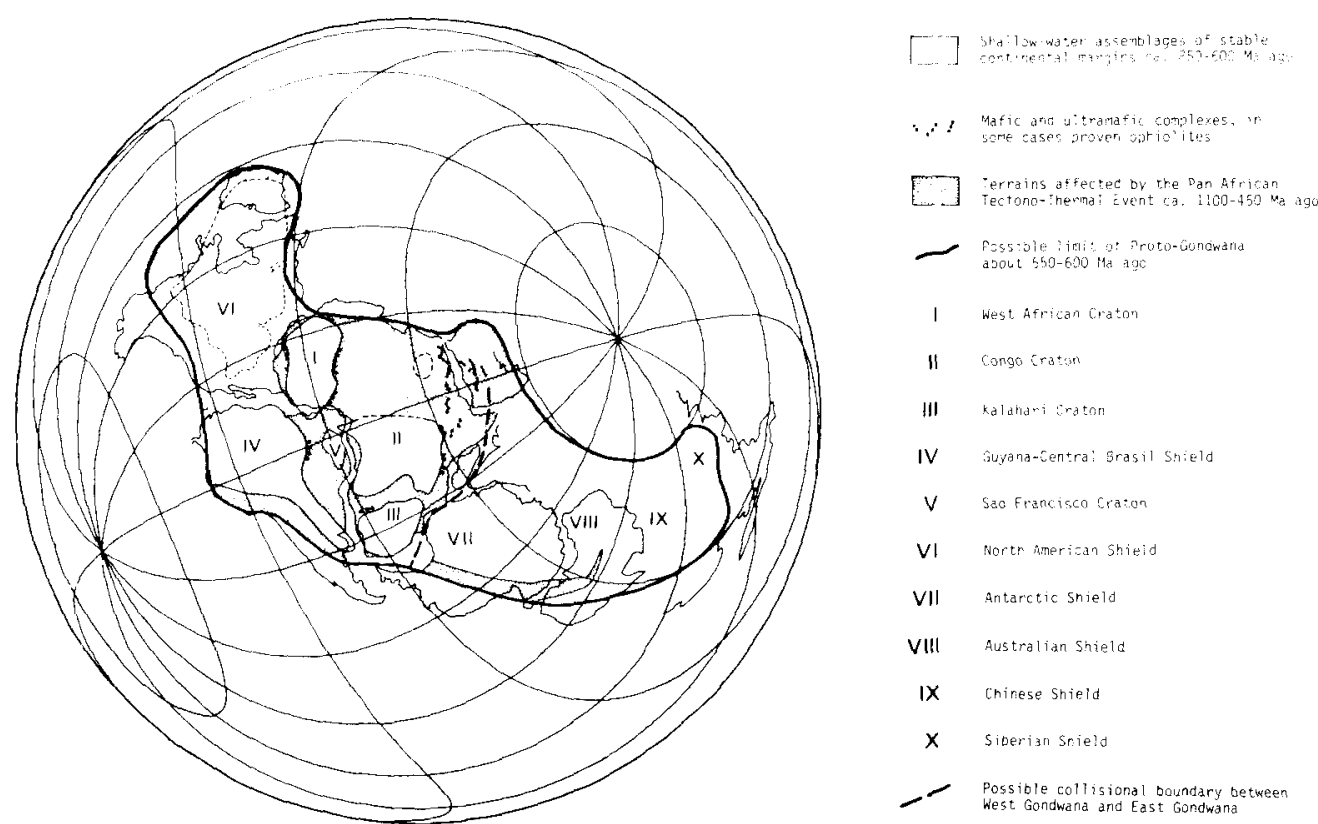

Figure 1. Possible configuration of proto-Gondwana supercontinent at the end of the Precambrian, showing distribution of Pan African terrains (modified after Black, 1978, and Morel and Irving, 1978). Note that new palaeomagnetic data (McWilliams, 1980; McWilliams et al., in press) suggest that this supercontinent only came into existence at about 550-600 Ma ago through collision of East Gondwana (Antarctica, India, Australia) with West Gondwana (Africa, South America and, perhaps, North America) east of the present Mozambique belt (see also Fig. 4, B). The possible suture is indicated and may extend into the Arabian Shield.

\section{Pan African Structural Types}

Four main types of Pan African development have been recognized; these are summarized by Kröner (1979) and are also illustrated in Figure 2.

(i) The "orogenic" belts consist of deformed thick "geosynclinal" sequences and show a depositional and tectonic development which may be broadly similar to that of many Phanerozoic orogens (for example, Nos. 4-12 in Fig. 2).

(ii) The "mobile" belts (for example, Nos. 2 and 3 in Fig. 2) consist of medium- to high-grade metamorphic rocks of which the majority represent structurally reconstituted older sialic basement, in some cases dating back to the Archaean (Kröner, 1977). The cover sediments, where recognized, are thin and of shallow-water type, and it is therefore suspected that these belts never went through a "geosynclinal" stage. As we shall see, this interpretation has considerable consequences for crustal evolution models.

(iii) Large parts of north-central and northern Africa are characterized by Pan African mineral ages and igneous activity, but corresponding penetrative tectonic effects are largely absent or not known. It would appear that in this region the Pan African event is solely manifested by strong thermal activity and represents a period of elevated heat flow.

(iv) A magmatic arc of considerable dimension is situated in NE Africa and Arabia and, together with the adjoining older basement to the west, constitutes the Arabian-Nubian Shield. The extensive development of thick calc-alkaline volcanic successions, together with genetically related granitoid intrusives and mafic to ultramafic complexes, at least in part of ophiolitic affinity, makes this Hijaz Arc (Fig. 2) the largest magmatic province of the continent. Its rock types and tectonic relationships are unlike those of the other Pan African terrains and most closely reflect conditions as seen in modern island arcs (Greenwood et al., 1976).

The significance of these different types with apparently contrasting tectonic evolution cannot be explained satisfactorily at present, mainly because cletailed knowledge of

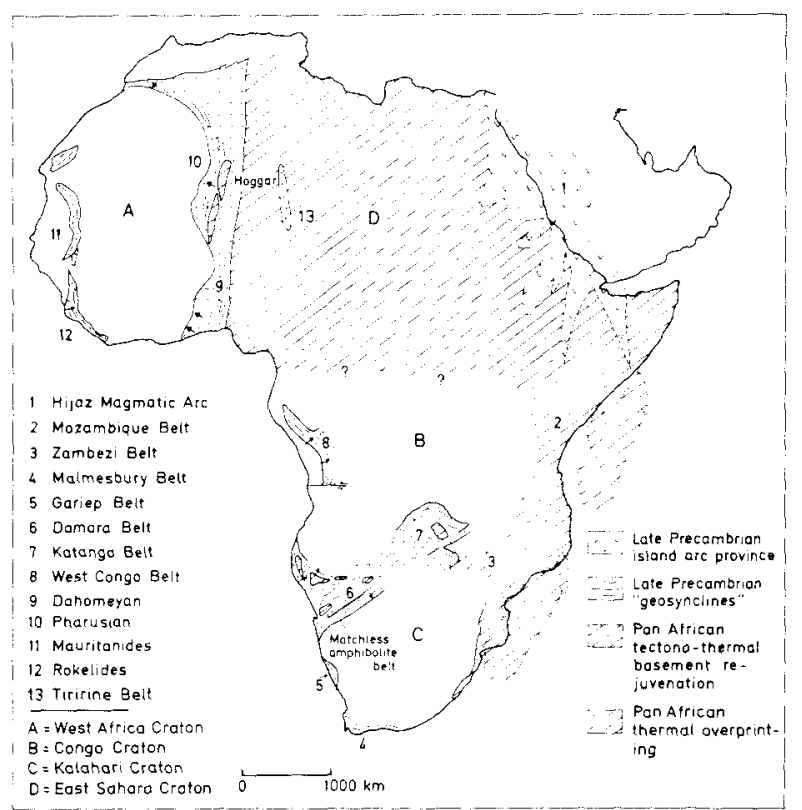

Figure 2. Areas affected by the late Precambrian to early Palaeozoic (ca. 1100-450 Ma) Pan African event. Arabia is rotated to close the Red Sea. Madagascar is in its two possible pre-Mesozoic positions (modified after Kröner, 1979).

important regions of the Pan African (such as in Mozambique, Zambia, Tanzania, Kenya, Ethiopia, Sudan, Central-African Republic, Tchad and Cameroun) is lacking and reliable age data are not available. Most work in recent years has concentrated on several "orogenic" belts such as the Damara and Gariep of Namibia, the West Congo and Katanga belts of Central Africa and the Dahomey-Pharusian belt of West Africa (see Kröner, 1979, for references), and considerable international interest in the development of the ArabianNubian Shield (Al-Shanti, 1979-80) has led to the establishment in 1979 of a new IGCP Project 2 .

1 Arabia is considered part of the African continent in pre-Tertiary times.

2 The Project, known as "Pan African crustal evolution in the Arabian-Nubian Shield" (No. 164) is under the direction of Project Leader Prof. A. Al-Shanti, Institute of Applied Geology, P.O. Box 1744, Jeddah, Saudi Arabia. 


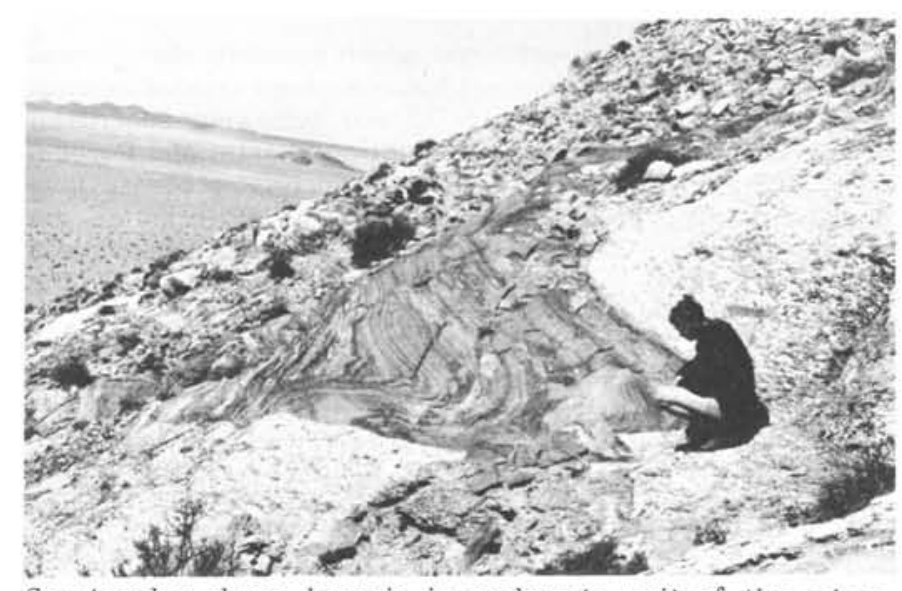

Spectacular slump breccia in carbonate unit of the miogeoclinal part of the Gariep belt, southern Namib Desert, Namibia.

\section{Tectonic Models}

\section{Mobilistic Interpretations}

Ever since plate tectonics became fashionable, attempts have been made to interpret the evolution of the Pan African belts in terms of the Wilson cycle of ocean opening and closing. The "orogenic" belts, in view of their pre-orogenic geosynclinal development, were seen in terms of collision of two continental margins, while the high-grade mobile zones (such as the Mozambique belt) were regarded as the uplifted and subsequently eroded portions of basement reactivation resulting from crustal thickening during Himalaya-type plate convergence (Burke and Dewey, 1972, and further references in Kröner, 1977 and 1979). The Hijaz Arc of Arabia was seen as a prime example of pre-Mesozoic ensimatic island arc growth and lateral continental accretion (Greenwood et al., 1976).

These mobilistic interpretations received considerable criticism from those who saw no ocean closure and subduction in the Pan African belts but favoured an "ensialic" evolution with crustal shortening in sialic-floored basins (see Kröner, 1977, and Martin and Porada, 1977 for discussion and references). Their arguments were that

(i) the African continent behaved as an essentially coherent unit during and before Pan African times, as indicated by palaeomagnetic data (see McElhinny and McWilliams, 1977, for discussion), thus ruling out large-scale motion of independent cratonic plates;

(ii) if orogeny took place virtually simultaneously in all Pan African belts as indicated by the then available geochronological data, it is geometrically and dynamically impossible that all belts resulted from collision; (iii) there are no blueschist assemblages as in Phanerozoic belts;

(iv) there are no true ophiolites in most belts and there is also a conspicuous lack of calc-alkaline magmatism except for the Pharusian belt of West Africa and the Hijaz Magmatic Arc;

(v) continuity of sialic basement can be demonstrated or inferred in several belts;

(vi) most collisional boundaries postulated by the mobilists are cryptic or are hallucino-sutures;

(vii) Precambrian oceanic crust was not subducted due to thermal constraints and Wilson-cycle evolution was therefore impossible.

\section{Transitional Tectonic Interpretation}

New field observations and laboratory results suggest that none of these contrasting views are entirely correct, and that the Pan African event represents a transitional tectonic regime between ca. $1100 \mathrm{Ma}$ and $\mathrm{ca} .500 \mathrm{Ma}$ ago during which both intraplate (ensialic) and plate margin (Wilson-cycle) orogeny may have taken place more or less simultaneously in different regions of the continent as well as in Gondwana as a whole (Kröner, 1979, 1980b). Recent results seem to substantiate this view.

1. Asynchronous Events: The tectono-thermal evolution during the Pan African event was more complex than hitherto assumed and geochronology shows that it was not synchronous throughout the continent. Figure 3 gives a simplified and comparative view of individual regions on the basis of available published and unpublished age data and it is evident that some belts (such as the Katangan and Mozambique) have a long and polyphase history, while others seem to display a relatively simple and short tectono-metamorphic development (for example, the Dahomey belt). These apparently "simple" belts will probably reveal a more complex history when additional detailed isotopic dating becomes available.

2. Ophiolites: At Bou Azzer in Morocco and at several localities in the Arabian-Nubian Shield in Egypt and Saudi Arabia, ophiolites that probably represent obducted fragments of late Precambrian ocean or back-arc basin floor have been identified. The Bou Azzer complex appears to be the most complete and best preserved piece of ca. $790 \mathrm{Ma}$ old oceanic crust (Leblanc, 1976), while other occurrences are tectonically dismembered but show many of the typical elements of ophiolites such as chert, pillow lava, sheeted dykes, layered gabbro, harzburgite and dunite with chromite pods. Mafic and ultramafic rocks associated with glaucophane-bearing schists and a possible trench mélange from the Gariep belt of coastal Namibia have also been described (Kröner, 1979; No. 5 in Fig. 2) and these may constitute a dismembered ophiolite.

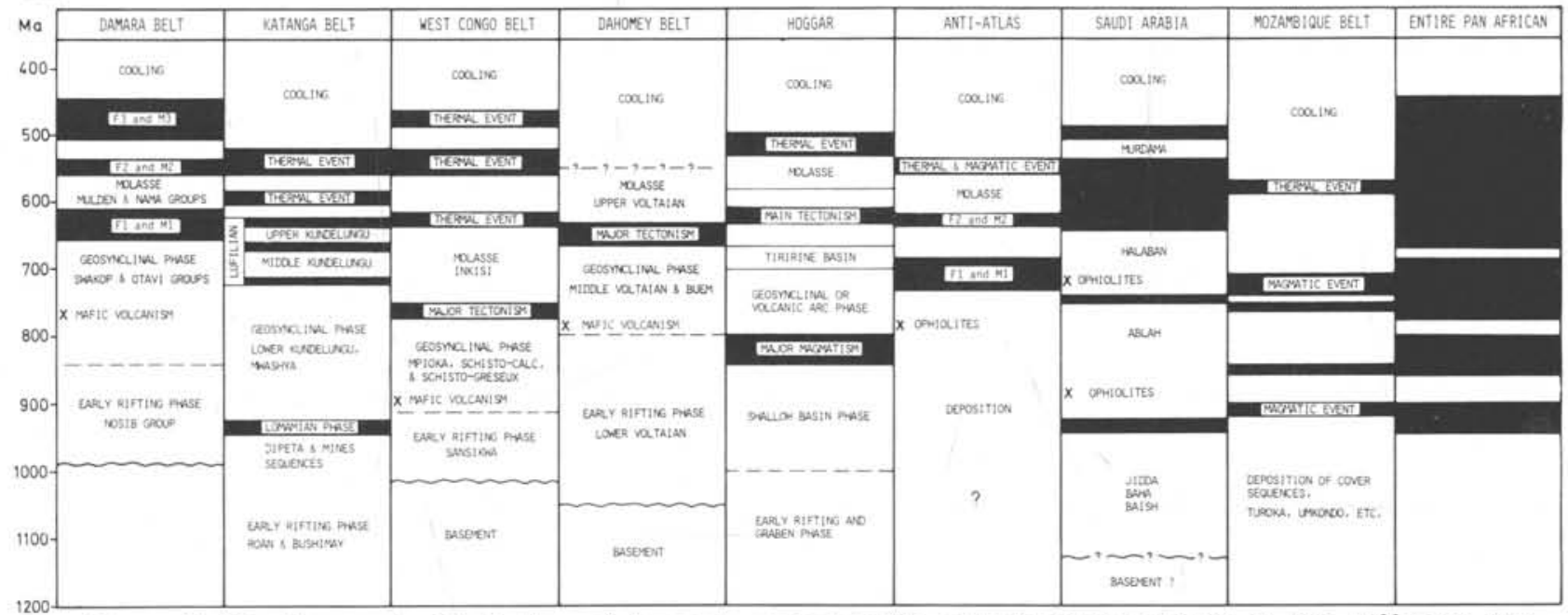

Figure 3. The temporal distribution of igneous, metamorphic and tectonic activity in the different Pan African terrains. Black bars denote approximate times of individual episodes or phases. Last column shows data from all regions combined. Based on published age data (available from the author on request). 


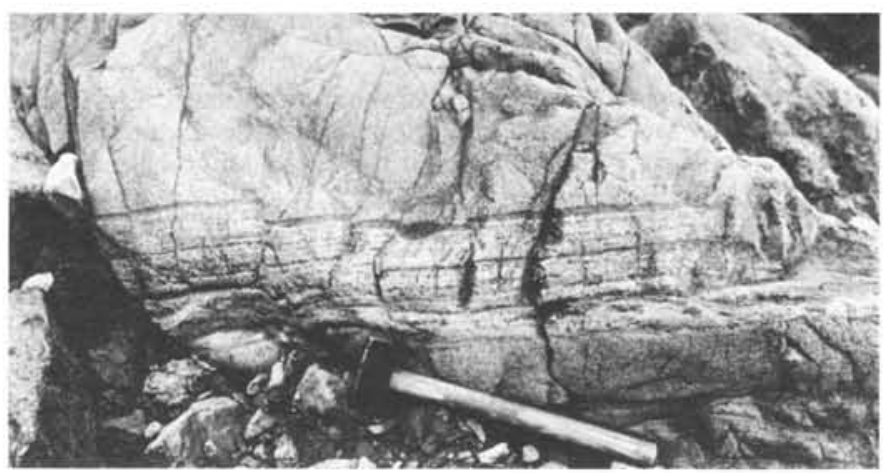

Layered gabbro from mafic-to-ultramafic complex at Rabigh, north of Jeddah, Saudi Arabia. This unit is overlain by sheeted dykes and pillow lavas and probably constitutes part of an ophiolite complex.

The identification of dismembered ophiolites in Arabia and Egypt occurring in association with calc-alkaline volcanics whose chemistry and $\mathrm{Sr}$-isotope systematics are indicative of island arc environments leaves little doubt that plate tectonic processes, probably similar to those of the presentday Pacific Ocean, may have operated in the late Precambrian. Detailed models of the crustal accretion process vary between Andean-type, marginal basin and ensimatic evolution and are the subject of international multidisciplinary research within IGCP Project No. 164. Limited palaeomagnetic data for Arabia and Egypt indicate that these regions were part of the African plate by about $600 \mathrm{Ma}$ ago (McWilliams, 1980) at which time the accretion process must have been virtually completed.

3. Passive and Active Margins: The Pan African assemblage in Mali and Algeria (No. 10 in Fig. 2) appears to have all the attributes of a passive continental margin (along the West African Craton) and an active margin (along the Tuareg Shield) which collided about $600-650 \mathrm{Ma}$ ago (Caby et al., 1980). Whether a wide Pan African ocean was destroyed during this process is uncertain, but considerable volumes of calc-alkaline volcanic greywacke and related intrusives argue for some subduction and generation of arc assemblages.

4. Ensialic Fold Belts: In contrast to the collisional orogeny which produced the Pharusian belt of the Western Hoggar, the apparently entirely ensialic Tiririne fold belt (No. 13 in Fig. 2) with up to $8000 \mathrm{~m}$ of clastic sediments was formed somewhat later - at about $600 \mathrm{Ma}$ in the eastern Hoggar (Bertrand et al., 1978). The floor of this belt is made up of pre-Pan African basement, and basin formation was probably related to crustal stretching during uplift after collision in the Pharusian belt, while deformation can be related to intraplate crustal shortening as a result of further collision and continental subduction farther west, similar in principle to the Recent deformation in Tibet and in the Tien-Shan following continental collision of India with Asia (Caby et al., 1980).

5. Ocean Opening and Closure: Evidence for limited ocean opening and closure without subduction of oceanic crust is accumulating for several Pan African belts of southern and central Africa. The Damara belt of Namibia is particularly interesting in this respect since it has many similarities with such Phanerozoic orogens as the Alps in containing well defined miogeoclinal and eugeoclinal rock assemblages which were intensely deformed during several phases of orogenic activity. These produced polyphase metamorphic rocks, large amounts of syntectonic and post-tectonic granitoids and spectacular nappe emplacement in the southern foreland of the belt.

In view of the absence of calc-alkaline volcanics or volcanicderived sediments and ophiolites (only a discontinuous belt of amphibolite is known from a flysch trough in the south), and the proven continuity of pre-Damara basement from the north into the centre of the belt, the destruction of a large ocean is considered unlikely during the Damara orogeny.
Models were therefore proposed which entailed the generation of an ensialic geosynclinal basin through crustal attenuation which was subsequently closed following subcrustal delamination and continental subduction (Martin and Porada, 1977; Kröner, 1979 and Fig. 4). Such a process, long repulsive to theoretical plate tectonicians who rejected the "subductibility" of continental crust, is now also considered a likely mechanism for crustal shortening in the Alps, the Apennines and the Colorado Plateau (see discussion in Kröner, 1980b) and is named A-subduction in honour of $\mathrm{O}$. Ampferer who first suggested "Verschluckung" of continental crust as a likely cause of orogenic deformation.

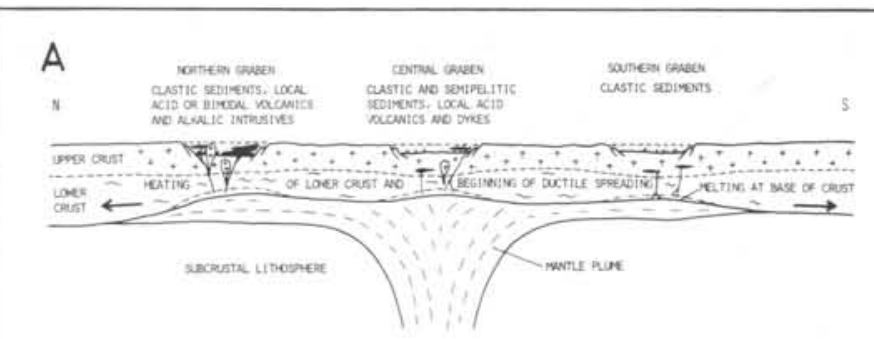

B
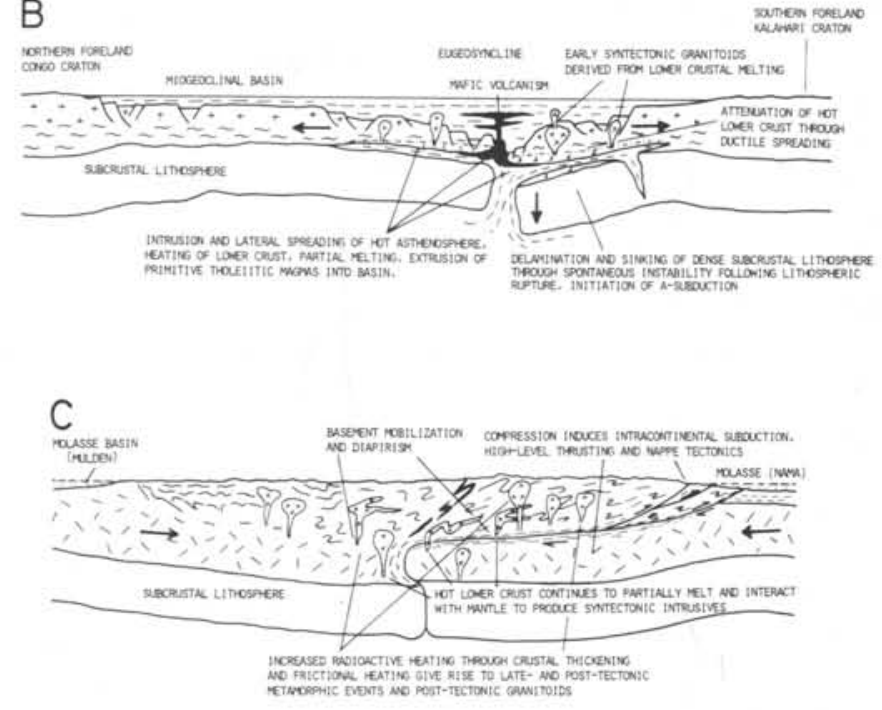

Figure 4. Simplified and schematic sections showing suggested evolution of the apparently ensialic Pan African Damara belt of Namibia through crustal thinning, delamination and intracrustal A-subduction. For detailed explanation of model see Kröner (1980b).

The results of detailed palaeomagnetic work in the Damara belt and on the two adjoining cratons are incompatible with any postulated large-scale relative motion of independent plates between Ca. $1000 \mathrm{Ma}$ and $600 \mathrm{Ma}$ ago (Fig. 5a) and thus support the above model (McWilliams, 1980).

Similar conclusions can be reached for the West Congo belt (No. 8 in Fig. 2) whose northern part consists of a broad ensialic basin where field relationships clearly reveal continuity of older basement under the Pan African geosynclinal sediments and no suture seems to be present (Cahen, 1978). Perhaps this belt evolved through a wedge-shaped opening and closing of a rift-related basin with the rotation axis close to its northern margin. For the Katanga belt of southeastern Zaire and Zambia, the available data also point to an ensialic evolution, particularly since the geosynclinal strata consist exclusively of sediments and syn-to post-tectonic granitoids are almost comple tely lacking.

6. Metamorphic Mobile Belts: The high-grade mobile belts such as the Zambezi and Mozambique have received little 


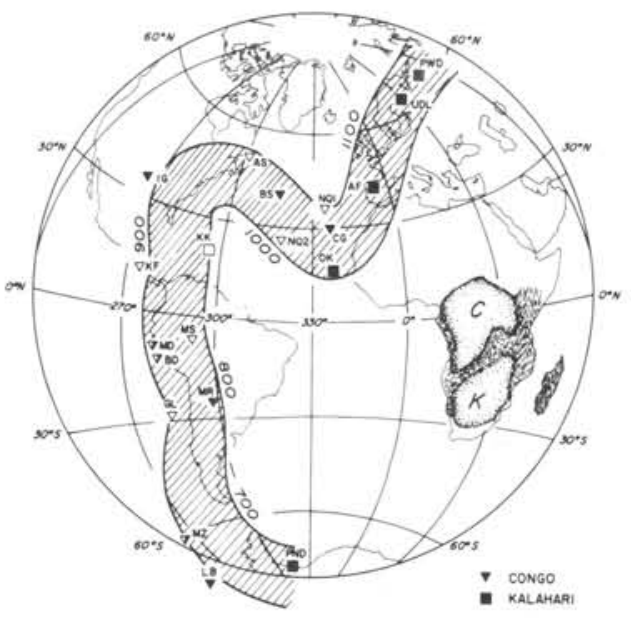

a) ago, suggesting that no large-scale motion of these crustal blocks relative to each other has taken place during that time (from McElhinny and McWilliams, 1977). (b) Pan African APWP for East and West Gondwana suggesting a collisional event in latest Precambrian to early Palaeozoic time (see also Fig. 1) from McWilliams et al., in press.

attention in recent years, and Kröner (1977, 1979) proposed an evolution following intraplate distortion within the large proto-Gondwana supercontinent. However, at least the Mozambique belt contains several mafic to ultramafic complexes that some researchers liken to tectonized ophiolites, and new palaeomagnetic data suggest that Africa and at least Australia were not part of the same continent in Pan African times but seem to have been involved in a collision about 550-600 Ma ago (McWilliams, 1980, see also Fig. 5b). It is possible that the Mozambique belt reflects this event and constitutes the leading eastern edge of the Pan African continent with the suture now concealed somewhere east of Madagascar.

Whatever the detailed mechanism, current information on these belts is inadequate for a reliable geodynamic interpretation and it is hoped that IGCP Project No. 164 will provide new insights from work in NE Africa.

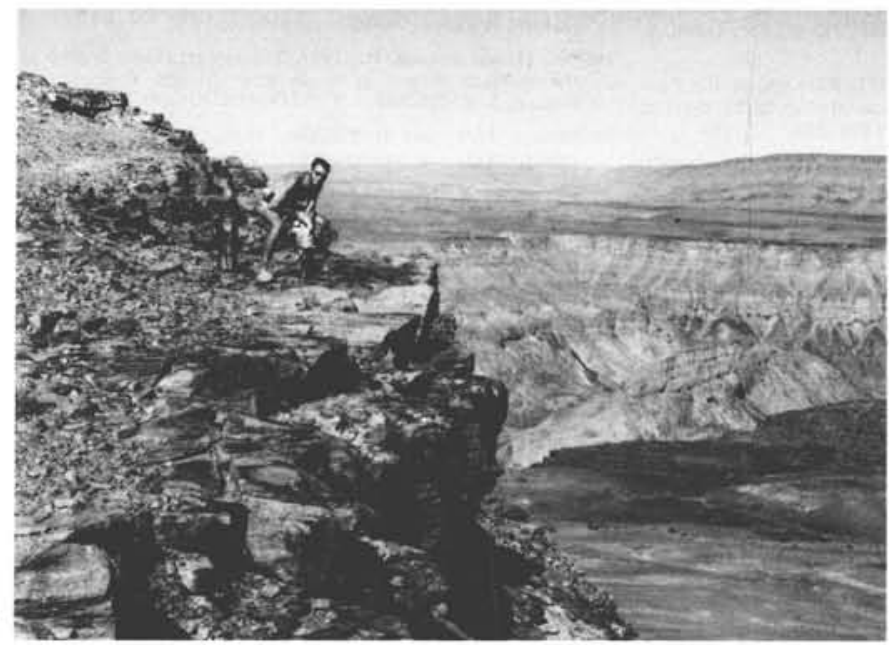

A. Kröner takes core samples for palaeomagnetic work along the edge of the Fish River Canyon in southern Namibia. The flat-lying sediments belong to the late Precambrian lower Nama Group and contain an Ediacara-type fauna.

\section{Pan African Belts and Ore Deposits}

There is little doubt that the "orogenic" belts and the Hijaz Magmatic Arc constitute, economically, the most important regions of the Pan African. Clifford (1966) observed that a large proportion of Africa's base mineral wealth occurs in belts of southern and central Africa, whereas the high-grade structurally reconstituted zones of East Africa are less well endowed and so far produce largely pegmatite minerals. The "geosynclinal" sequences contain either syngenetic stratiform massive sulfide deposits, probably related to submarine fumarolic exhalations, or stratiform Kupferschiefer-type mineralization found in specific pelitic horizons of the stratigraphic sequences. It may well be advisable to launch major mineral exploration surveys in the Pan African belts of West Africa to search for similar deposits.

The Katanga and Damara belts are also major producers of uranium and, in the latter, mineralization occurs in pegmatites and alaskitic granites which have now been found to represent remobilized (ca. $2 \mathrm{Ga}$ old) basement. 'This justifies a new look at the large areas of reconstituted basement and Pan African granitoids in the Mozambique belt and in north-central Africa where similar ore deposits may be expected.

The Hijaz Arc contains small deposits of gold in the ophiolitic zones and small massive sulfide occurrences of Kuroko-type have also been discovered. Exploration here and in neighbouring Egypt, Sudan and Yemen may locate further deposits, but the main target should perhaps be the search for porphyry copper deposits of the type known from post-Mesozoic subduction-related magmatic arcs.

\section{Conclusions}

The Pan African belt system displays evidence of a complex crustal evolution which took place in several phases during the period ca. $1100 \mathrm{Ma}$ to about $450 \mathrm{Ma}$ ago. Some belts clearly indicate that modern-type plate tectonic processes were already at work in the late Precambrian, while other regions suggest a development not involving plate separation and subduction of oceanic crust. If this is correct, the Pan African may represent a tectonic regime transitional between predominantly intraplate deformation of the older Precambrian and predominantly plate margin deformation of the Phanerozoic. The first occurrence of true ophiolites with evidence for sea-floor spreading (sheeted dykes) may signify this change in global tectonics and one may speculate that Pan African crustal evolution also reflects a change in the mantle convection system as a result of the continuous decline in heat flow from the interior of the earth.

The discussion on Pan African tectonism will no doubt continue, though two general conclusions should be borne in mind:

(i) The duration of the Pan African event (550 Ma) exceeds that of Phanerozoic orogenies by 100 per cent or more. This and the considerable duration of individual tectonic episodes 
(Fig. 3) suggests that tectonic processes were slower than in modern collision systems and may therefore not have produced mountain belts (Gaudette and Hurley, 1979).

(ii) The generalized application of Wilson-cycle models as proposed for Phanerozoic collision belts may perhaps not be justified in view of the increasing evidence favouring nonuniformitarian crustal evolution through time (Kröner, 1980b). This is not to say that plate tectonics did not operate during the Precambrian, but it is likely that somewhat different plate interaction at that time produced different effects in the rocks that we now see, and the excellent exposures in some Pan African terrains should enable us to decipher this process.

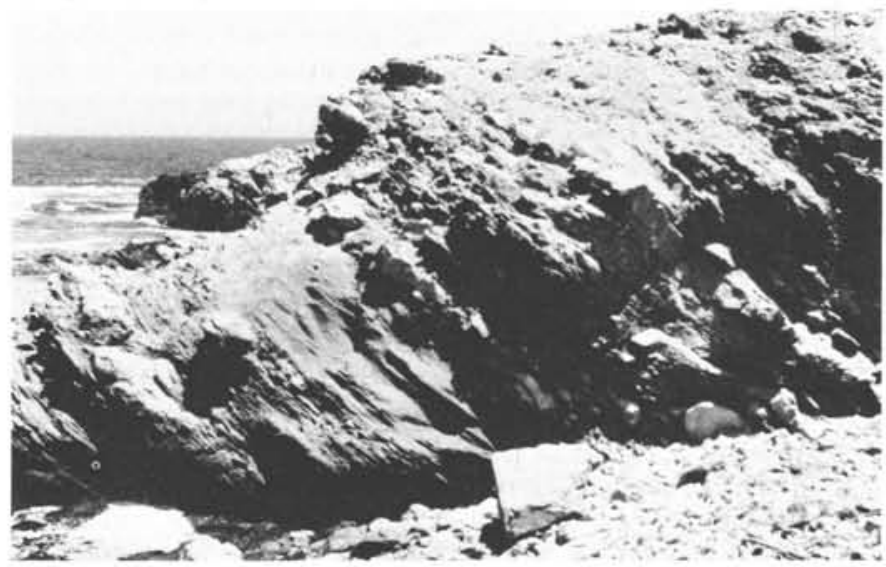

Tectonic mélange associated with mafic volcanic rocks of the Gariep belt near Alexander Bay, South Africa. The dark rocks are sheared basaltic andesites and tuffs, the light rocks are massive dolomite beds and lenses.
Lastly, in coming back to the problem of definition of the Pan African, some want the term restricted to the continentwide peak of metamorphism at $500+50 \mathrm{Ma}$; others wish to include the entire tectogenetic cycle from deposition to final consolidation. Kennedy (1964) clearly meant to specify the entire structural differentiation of an original shield into orogenic areas and, according to present data, this started between $1100 \mathrm{Ma}$ and $1000 \mathrm{Ma}$ ago. In this sense, the Pan African constitutes one of the major crust-forming events of earth history, and the term should therefore be applied accordingly. Individual episodes of the Pan African should be named after the areas in which they are observed, as, for example, the Damara, Katanga, and Pharusian episodes. It may eventually also become advisable to extend the term to other Gondwana continents or to devise a new name that could be applied to all these regions.

Recent and forthcoming meetings with emphasis on Pan African geology:

February 6-16, 1978: Symposium on Evolution and Mineralization of the Arabian-Nubian Shield. Institute of Applied Geology, King Abdulaziz University, Jeddah, Saudi Arabia, convened by A.M.S. Al-Shanti (Proceedings published in 4 volumes 1979-1980 for Institute of Applied Geology by Pergamon Press, Oxford).

October 6-15, 1979: 5th Conference on African Geology. Geological Society of Africa, Geological Survey of Egypt, Cairo. Papers will be published in a special issue of the Annals of the Geological Survey of Egypt.

April 1981: 11th Colloquium on African Geology. Dept. of Earth Sciences, The Open University, Milton Keynes, U.K. For further information contact Dr. A. Ries at this address.

\section{References}

Al-Shanti, A.M.S. (Convener), 1979-80, Evolution and mineralization of the Arabian-Nubian Shield. Proceedings of a symposium: Pergamon Press, Oxford, 4 vols.

Bertrand, J.M.L., Lancelot, J.R., Moussine-Pouchkine, A. and Sadallah, A., 1978, The late Pan-African intracontinental linear fold belt of the eastern Hoggar (central Sahara, Algeria): geology, structural development, U-Pb geochronology, tectonic implications for the Hoggar shield: Precambrian Res., v. 7, p. 349-376.

Bessoles, B., 1977, Géologie de l'Afrique: Le craton ouest. africain: Bur. Rech. geol. min. France, Mém. 88, 402 p.

Black, R., 1978, Propos sur le Pan-Africain: 5oc. géol. France, Bull, v. 20, p. 843-850.

Burke, K.C. and Dewey, J.F., 1972, Orogeny in Africa, in Dessauvagie, T.F.J. and Whiteman, A.J. (eds.), African geology: Ibadan University Press, Ibadan, p. 583-608.

Caby, R., Bertrand, J.M. and Black, R., 1980, Pan-African ocean closure and continental collision in the Hoggarlforas segment, central Sahara, in Kröner, A. (ed.), Precambrian plate tectonics: Elsevier, Amsterdam, in press.

Cahen, L., 1978, La stratigraphie et la tectonique du Supergroupe Ouest-Congolien dans les zones mediane et externe de l'Orogenese Ouest-Congolien (Pan-Africain) at Bas-Zaire et dans les regions voisines: Mus, roy, Afr. centre., Tervuren, Ann., Série in- $8^{\circ}$, Sci. Geol., no, 83, $150 \mathrm{p}$.

Clifford, T.N., 1966, Tectono-metallogenic units and metallogenic provinces of Africa: Earth Planet. Sci. Lett., v. 1, p. $421-434$.

Clifford, T.N., 1967, The Damaran episode in the Upper

Proterozoic - Lower Paleozoic structural history of southern Africa: Geol, Soc. America, Spec. Paper 92, 100 p.

Fleck, R.J., Greenwood, W.R., Hadley, D.G., Anderson, R.E. and Schmidt, D.L., 1979, Rubidium-strontium geochronology and plate tectonic evolution of the southern par: of the Arabian shield: U.S. Geol. Surv. Saudi Arabian Project, Rep. 245, 105 p.

Gass, 1.G., 1977, The evolution of the Pan African crystalline basement in NE Africa and Arabia: J. Geol. Soc. Lond., v, 134, p. 129-138.

Gaudette, H.E. and Hurley, P.M., 1979, Where were the PanAfrican mountains? No evidence of 500 M.Y. detrital zircons: Tectonophysics, v. 54, p. 211-230.

Greenwood, W.R., Anderson, R.E., Fleck, R.J. and Schmidt, D.L., 1976, Late Proterozoic cratonization in southwestern Saudi Arabia: Phil. Trans. R. Soc., v. 280A, p. 515-527.

Kennedy, W.Q., 1964, The structural differentiation of Africa in the Pan-African ( 500 m.y.) tectonic episode: Res. Inst. Afr, Geol., Univ. of Leeds, 8th Ann. Rep., p. 48-49.

Kröner, A., 1977, Precambrian mobile belts of southern and eastern Africa - ancient sutures or sites of ensialic mobility? A case for crustal evolution towards plate tectonics: Tectonophysics, y, 40, p. 101-135.

Kröner, A., 1979, Pan-African mobile belts as evidence for a transitional tectonic regime from intraplate orogeny to plate margin orogeny, in Tahoun, S.A. (ed.), Evolution and mineralization of the Arabian-Nubian shield: Pergamon Press, Oxford, v. 1, p. 21-37.
Kröner, A., 1980a, Chronologic evolution of the Pan-African Damara belt in Namibia, southwestern Africa, in Neumann, J. (ed.), Mobile earth. Final report of the Geodynamics Project, Federal Republic of Germany: Boldt Verlag, Boppard, in press.

Kröner, A., 1980b, Precambrian plate tectonics, in Kröner, A. (ed.), Precambrian plate tectonics: Elsevier, Amsterdam, in press.

eblanc, M., 1976, Proterozoic oceanic crust at Bou Azzer: Nature, v. 261, p. $34-35$

Martin, H. and Porada, H., 1977, The intracratonic branch of the Damara orogen in South West Africa: Precambrian Res., v. 5, p. 311-357.

McElhinny, M.W. and McWilliarns, M.O., 1977, Precambrian geodynamics - a paleomagnetic view: Tectonophysics, v. 40. p. $137-160$

McWilliams, M.O., 1980, Palaeomagnetism and the Precambrian tectonic evolution of Gondwana, in Kröner, A. (ed.) Precambrian plate tectonics: Elsevier, Amsterdam, in press.

McWilliams, M.O., McElhinny, M.W. and Kröner, A., Pan African tectonics: evidence from paleomagnetism: Earth Planet. Sci. Lett., in press.

Morel, P. and Irving, E., 1978, Tentative paleocontinental maps for the early Phanerozoic and Proterozoic: Jour. Geol., v. 86, p. 535-561.

Vail, J.R., 1964, The Mozambique belt of eastern Africa: Res. Inst. Afr. Geol., Univ. Leeds, 8 th Ann. Rep., p. $32-34$.

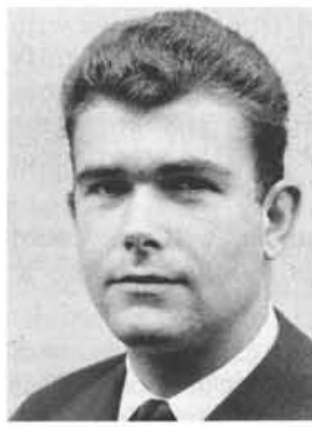

ABOUT THE AUTHOR: Professor of Geology and currently Chairman of the Department of Geosciences at the University of Mainz, Federal Republic of Germany, Dr. Alfred Kröner started work on the Precambrian geology of southern Africa as Senior Research Fellow of the Precambrian Research Unit, University of Cape Town, South Africa, after receiving his Ph.D. there in 1968. He has travelled widely in Africa and his research interests include Archaean and Pan African crustal evolution. After returning to Germany in 1977, he continued his work in Africa and also became involved in research in Saudi Arabia. $\mathrm{He}$ is one of the coordinators for the CGMW Tectonic Map of Africa, a member of the IUGS Subcommission on Precambrian Structural Type Regions, as well as a participant in several IGCP Projects. 